\title{
PENGARUH WAKTU PEMBERSIHAN GULMA DAN POLA TANAM TERHADAP PERTUMBUHAN DAN HASIL PADI SAWAH (Oryza sativa L.)
}

\section{The Effect Of Weeding Time And Cropping Pattern On The Growth And Yield Of Paddy Rice (Oryza sativa L.)}

\author{
Dedi Hermawan Hutagaul, Bilman W. Simanihuruk, Herry Gusmara \\ Agroekoteknologi Universitas Bengkulu, \\ bilmanwilmansimanuhuruk@yahoo.co.id
}

\begin{abstract}
ABSTRAK
Penelitian ini bertujuan untuk mengetahuiwaktu pembersihan gulma padatanaman padi sawah terhadap pertumbuhan dan hasilnya, mengetahui pola tanam terbaik yang mampu meningkatkan pertumbuhan dan hasil tanaman padi sawah, dan mengetahui interaksi antara pola tanam dan waktu pembersihan gulma terhadap pertumbuhan dan hasil tanaman padi sawah.Penelitian dilakukan di lahan percobaan Fakultas Pertanian, Universitas Bengkulu, Bengkulu dengan jenis tanah histosol (gambut). Penelitian dilakukan dari Bulan Januari sampai April 2017.Penelitian ini disusun menggunakan rancangan acak kelompok lengkap (RAKL) dengan 2 faktor yaitu pola tanam dan waktu pengendalian gulma pola tanam terdiri atasjajar legowo $(2: 1)$ jarak antar legowo $30 \mathrm{~cm}$ dan jarak tanam di dalam legowo $20 \mathrm{~cm} \times 10 \mathrm{~cm}$, dantegel $(25 \mathrm{~cm} \times 25 \mathrm{~cm})$ dan waktu pengendalian gulma terdiri atas pembersihan gulma pada umur 3 MST, pembersihan gulma pada umur 5MST, pembersihan gulma pada umur 7MST, pembersihan gulma pada umur 3dan 5MST, dan pembersihan gulma pada umur 5dan 7MST. Hasil penelitian menunjukkan bahwa waktu pembersihan gulma 5 dan 7 minggu setelah tanam menghasilkan tinggi tanaman tertinggi yaitu 144,32 cm, dan berat gabah per rumpun terberat yaitu 43,91 gram. Sedangkan pola tanam jajar legowo menghasilkan indeks luas daun terluas yaitu 9,78. Pola tanam tegel menghasilkan tinggi tanaman tertinggi yaitu $112,28 \mathrm{~cm}$, jumlah anakan produktif terbanyak yaitu 15,55 batang, dan bobot gabah kering terberat yaitu 43,91 gram. Interaksi pola tanam tegel dan waktu pembersihan gulma 3 minggu setelah tanam menghasilkan jumlah anakan produktif terbanyak yaitu 17,23 batang.Pola tanam legowo memberikan hasil padi tertinggi setara dengan $5,74 \mathrm{~kg}$ GKG per petak (6 $\mathrm{m}^{2}$ ). Sebaliknya, pola tanam tegel hanya menghasilkan 4,22 kg GKG per plot
\end{abstract}

Kata kunci: Gulma, Padi, Pola Tanam

\begin{abstract}
The purpose of this research is to know the weeding time on the growth and yield of paddy rice, to know the best cropping pattern that can increase the growth and yield of paddy rice, and to know the interaction between cropping pattern and weeding time to growth and yield of paddy rice. The research was conducted in experimental field of Agriculture Faculty, University of Bengkulu, Bengkulu with Histosol soil type. The study was conducted from January to April
\end{abstract}


2017.This study used a randomizedcomplete block design (RCBD) with two factors i.e. cropping pattern and weeding time. Cropping patterns were consist of legowo 2:1 (distance between legowo $30 \mathrm{~cm}$ and spacing in legowo $20 \mathrm{~cm}$ x 10 $\mathrm{cm}$ ) and tile cropping pattern (spacing $25 \mathrm{~cm}$ x $25 \mathrm{~cm}$ ). Weeding times were consist of weeding time at 3 week after planting (WAP), 5 WAP, 7 WAP, 3 and 5 WAP, and 5 and 7 WAP.The results showed that weeding time 5 and 7 WAP resulted in the highest plant height of $144.32 \mathrm{~cm}$, and weight of grain per hedge was 43.91 grams. While the legowo cropping pattern produced the widest leaf area index of 9.78. The tile cropping pattern yields the highest plant height that is $112,28 \mathrm{~cm}$, the highest number of productive tiller is $15,55 \mathrm{stems}$, and the weight of dried grain is 43,91 gram. The interaction of cropping pattern and weeding time 3 WAP result in the highest number of productive tillers 17,23 stems. The legowo cropping pattern gives the highest rice yield equivqlent to $5.74 \mathrm{~kg}$ weight of dried grain per plot $\left(6 \mathrm{~m}^{2}\right)$. On the contrary, tile cropping pattern gives only $4,22 \mathrm{~kg}$ weight of dried grain per plot.

Key Words: Cropping Pattern, Rice, Weed

\section{PENDAHULUAN}

Padi merupakan bahan pangan utama sumber karbohidrat yang sangat penting bagi kebutuhan masyarakat Indonesia.Kebutuhan akan beras baik untuk bahan pangan, pakan ternak, maupun bahan baku industri terus meningkat seiring pertambahan jumlah penduduk. Keadaan tersebut menuntut untuk dilakukan peningkatan jumlah dan kualitas produksi padi (Hermawati, 2012).Produksi padi di Provinsi Bengkulu pada tahun 2013 sebanyak 4,21 ton gabah kering giling/ha, sedangkan pada tahun 2014 menurun menjadi 4,02 ton/ha(Badan Pusat Statistik, 2014).Permasalahan yang dihadapi dalam pemenuhan kebutuhan beras saat ini antaralain adalah semakin banyaknya lahan pertanian yang mengalami konversi menjadi lahannon pertanian, menurunnya tenaga kerja produktif di sektor pertanian, danmenurunnya produktivitas lahan sehingga memerlukan pengelolaan denganteknologi yang tepat (Purwono dan Purnamawati, 2007).

Upaya meningkatkan produksi padi sering dilakukan melalui pemupukan, namun jarang diperhatikan keberadaan gulma dilahan pertanaman. Padahal pertumbuhan gulma lebih cepat, perkembangan populasinya sangat pesat, dan mampu bersaing dengan tanaman yang dibudidayakan. Gulma merupakan 
tanaman penggangguyang berkompetisi dengan tanaman utama dalam mendapatkan unsur hara, cahaya matahari, air dan ruang tumbuh (Moenandir, 1988). Keberadaan gulma yang dibiarkan tumbuh bersama dengantanaman utama hingga panen mampu menurunkan hasil sebesar 20-80\%. Gulma merupakan kendala agronomis dalam peningkatan produksi padi (Sukman dan Yakup, 2002).Hasil penelitian Rudiyono (2016) menunjukkan bahwa frekuensi penyiangan gulma yang disiang tiga kalimemiliki pertumbuhan dan hasil padi yang lebih tinggi dibandingkan dengan tanpa disiang, disiang satu kali, dan disiang dua kali. Penyiangangulma sebanyak tiga kali, dua kali, dan satu kalimampu meningkatkan bobot gabah kering panensebesar 27,73\%, 13,44\%, dan 4,20\% lebih besardibandingkan tanpa penyiangan.

Faktor lain yang mempengaruhi pertumbuhan dan hasil padi sawah adalah pola tanam. Terdapat dua jenis pola tanam yang sering digunakan yaitu jajar legowo dan tegel (Ihwani et al., 2013). Pengaturan jarak tanam didalam legowo membuat ruang tumbuh untuk gulma semakin berkurang (Suriapermana et al.,2000).Jarak tanam yang tepat akanmemberikan pertumbuhan, jumlah anakan,dan hasil yang maksimum. Menurut Sohelet al. (2009), jarak tanam yang optimumakan memberikan pertumbuhan bagian atas tanaman yang baik sehingga dapatmemanfaatkan lebih banyak cahayamatahari dan pertumbuhan bagian akaryang juga baik, sehingga dapat memanfaatkan lebih banyak unsur hara.Sebaliknya, jarak tanam yang terlalu rapatakan mengakibatkan terjadinya kompetisiantar tanaman yang sangat hebat dalamhal cahaya matahari, air, dan unsur hara.Akibatnya,pertumbuhantanamanterhambat dan hasil tanaman rendah.

Hasil penelitian Pahrudin et al. (2004) menyimpulkan bahwa sistem tanam jajar legowo memiliki beberapakelebihan yaitu sinar matahari dapat dimanfaatkan lebih banyak untuk fotosintesis serta pemupukan dan pengendalian organisme pengganggu tanaman menjadi lebih mudah dilakukan di dalam loronglorong.Hasil penelitian yang dilakukan BPTP (2010) menunjukkan bahwa sistem tanam jajar legowomampu menghasilkan gabah lebih tinggi dibandingkan dengan jarak tanam tegel dengan kenaikan hasil mencapai 1,2 ton GKG/ha.Sistem tanam legowo merupakan cara tanam padi sawah dengan pola beberapa barisan tanaman yang diselingi satu barisan kosong. 
Perubahan jarak tanam akan menyebabkan komponen-komponen hasil padi akan berubah pula (Partohardjono dan Makmur,1989). Jarak tanam yang rapat akan menyebabkan sistem perakaran tanaman akan lebih awal memanfaatkan pupuk N (Masdaret et.al., 2005).Penerapan pola tanam dengan jajar legowo dapat menghasilkan 8,6 ton/ha gabah kering panen dari pada teknologi petani dengan sistem tanam tegel yang hanya menghasilkan 6,0 ton/ha GKP (BPTP, 2013).

Penelitian ini bertujuan untuk mengetahui (1) waktu pembersihan gulma padatanaman padi sawah yang dapat mempengaruhi pertumbuhan dan hasil padi sawah, (2) pola tanam terbaik yang dapatmeningkatkan pertumbuhan dan hasilpadi sawah, dan (3) interaksi perlakuan pola tanam dan waktu pembersihan gulma terhadap pertumbuhan dan hasil padi sawah.

\section{METODE PENELITIAN}

Penelitian ini dilaksanakan mulai dari Bulan Januari sampai April 2017 di lahan percobaan Fakultas Pertanian, Universitas Bengkulu, Jenis Tanah Histosol, Ketinggian tempat $10 \mathrm{~m}$ dpl. Bahan yang digunakan dalam penelitian ini adalah benih padi varietas surya, pupuk dasar (Urea, SP-36, $\mathrm{KCl}$ ), insektisida Dharmabas dan Envoy. Alat yang digunakan antara lain traktor tangan, cangkul, parang, bambu, tali rafia, gunting, kamera, alat tulis, hand sprayer,jaring burung, meteran, koran, kantong plastik, necis, timbangan analitik, dan alat lain yang menunjang pelaksanaan penelitian.

Penelitian ini menggunakan rancangan acak kelompok lengkap (RAKL) dengan 2 faktor. Faktor pertama adalahpola tanam (T) yang terdiri dari dua taraf yaitu :Jajar legowo 2:1(jarak antar legowo $30 \mathrm{~cm}$ dan jarak tanam di dalam legowo $\left.20 \mathrm{~cm} \times 10 \mathrm{~cm}\left(\mathrm{~T}_{1}\right)\right)$ dan tegel dengan jarak tanam $25 \mathrm{~cm} \times 25 \mathrm{~cm}\left(\mathrm{~T}_{2}\right)$. Faktor kedua adalah waktu pembersihan gulma(P) yang terdiri dari 5 taraf yaitu:pembersihan gulma pada umur 3 minggu setelah tanam (MST) $\left(\mathrm{P}_{1}\right)$,pembersihan gulma pada umur 5MST $\left(\mathrm{P}_{2}\right)$, pembersihan gulma pada umur 7MST $\left(\mathrm{P}_{3}\right)$, pembersihan gulma pada umur 3dan 5MST $\left(\mathrm{P}_{4}\right)$, dan pembersihan gulma pada umur 5dan 7MST $\left(\mathrm{P}_{5}\right)$. Dari kedua faktor tersebut diperoleh10 kombinasi perlakuan yang setiap perlakuan diulang 3 kali ulangan.Dengan 
demikian, terdapat 30 satuan percobaan. Satuan percobaan berupa petak berukuran $2 \mathrm{~m}$ x $3 \mathrm{~m}$. Jarak antar petak 0,5 m dan jarak antar ulangan $1 \mathrm{~m}$.

Peubah yang diamati meliputitinggi tanaman $(\mathrm{cm})$, jumlah anakan total per rumpun (batang), indeks luas daun (ILD), jumlah anakan produktif (batang), panjang malai $(\mathrm{cm})$, jumlah gabah per malai, persentase gabah hampa per malai tanaman padi, bobot gabah kering giling (GKG) per rumpun (g), dan bobot 1000 bulir gabah $(\mathrm{g})$.

Data hasil pengamatan dianalisis menggunakan sidik ragam (uji F). Sebelum dilakukan uji lanjut terlebih dahulu data diuji normalitas, apabila data yang didapat tidak normal, maka dilakukan transformasi data. Apabila hasil sidik ragam menunjukkan pengaruh nyata, analisis dilanjutkan dengan uji lanjut Duncan's Multiple Range Test (DMRT) pada taraf nyata 5\%.

\section{HASIL DAN PEMBAHASAN}

Lahan yang digunakan pada penelitian ini merupakan lahan tadah hujan, sehingga kebutuhan air sangat tergantung kepada air hujan. Jenis tanah yang digunakan adalah Histosol (Gambut) dengan ketebalan gambut $\pm 100 \mathrm{~cm}$. Hama yang menyerang tanaman padi adalah walang sangit, belalang, penggerek batang, dan burung, penyakit yang menyerang, adalah busuk batang. Hama yang menyerang tanaman padi dikendalikan dengan melakukan penyemprotan insektisida Dharmabas, sedangkan penyakit busuk batang dikendalikan penyemprotan fungisida Envoy.

Kondisi curah hujan rata-rata saat penelitian bulan (Januari - April), data curah hujan rata-rata bulan Januari mencapai 246,8 mm, Februari mencapai 709,5 mm, Maret mencapai 290,8 mm, dan pada April mencapai 417,2 mm (BMKG, Prov. Bengkulu, 2017). Kondisi iklim tersebut mendukung pertumbuhan padi yang memerlukan rata-rata curah hujan200 mm/bulan (Bayong, 2004).

Data hasil pengukuran peubah yang diamati dianalisis menggunakan sidikragam dengan uji $\mathrm{F}$ taraf $5 \%$. Rangkuman hasil sidik ragam disajikan pada Tabel 1. 
Tabel 1. Rangkuman hasil sidik ragam peubah pengamatan

\begin{tabular}{|c|c|c|c|c|}
\hline \multirow[b]{2}{*}{ Peubah } & \multicolumn{4}{|c|}{ F-hitung } \\
\hline & Pola Tanam & $\begin{array}{c}\text { Waktu } \\
\text { Pembersihan } \\
\text { Gulma }\end{array}$ & Interaksi & $\begin{array}{l}\mathrm{KK} \\
(\%)\end{array}$ \\
\hline Tinggi tanaman & $9,55 * *$ & $3,83 *$ & $1,88 \mathrm{~ns}$ & 3,36 \\
\hline $\begin{array}{l}\text { Jumlah anakan per } \\
\text { rumpun }\end{array}$ & $2,20 \mathrm{~ns}$ & $0,98 \mathrm{~ns}$ & $0,61 \mathrm{~ns}$ & 10,58 \\
\hline Indeks luasa daun & $248,45 * *$ & $0,42 \mathrm{~ns}$ & $0,35 \mathrm{~ns}$ & 6,15 \\
\hline Jumlah anakan produktif & $14,44 * *$ & $0,25 \mathrm{~ns}$ & $2,96 *$ & 11,53 \\
\hline Panjang malai & $0,02 \mathrm{~ns}$ & $0,67 \mathrm{~ns}$ & $0,72 \mathrm{~ns}$ & 6,66 \\
\hline $\begin{array}{l}\text { Jumlah bulir gabah per } \\
\text { malai }\end{array}$ & $0,25 \mathrm{~ns}$ & $2,71 \mathrm{~ns}$ & $0,29 \mathrm{~ns}$ & 2,41 \\
\hline Bobot 1000 butir gabah & $0,05 \mathrm{~ns}$ & $0,08 \mathrm{~ns}$ & $1,06 \mathrm{~ns}$ & 6,59 \\
\hline $\begin{array}{l}\text { Persentase gabah hampa } \\
\text { per malai }\end{array}$ & $0,24 \mathrm{~ns}$ & $1,50 \mathrm{~ns}$ & $0,19 \mathrm{~ns}$ & 7,84 \\
\hline $\begin{array}{l}\text { Bobot gabah kering giling } \\
\text { per rumpun }\end{array}$ & $17,01 * *$ & $0,83 \mathrm{~ns}$ & $0,51 \mathrm{~ns}$ & 13,34 \\
\hline
\end{tabular}

Hasil penelitian menunjukkan bahwa pola tanam tegel menghasilkan tinggi tanaman tertinggi yaitu $112,28 \mathrm{~cm}$, sedangkan pola tanam jajar legowo menghasilkan tinggi tanaman terrendah yaitu 108,10 cm (Tabel 2). Hal ini diduga pola tanam jajar legowo jarak tanamnya lebih sempit dari pada pola tanam tegel, sehingga jumlah tanamannya lebih banyak dari pada pola tanam tegel. Pada kondisi tanaman yang lebih banyak maka daun tanaman akan saling menutupi, sehingga penangkapan cahaya menjadi semakin berkurang. Lin et al.(2009), menyatakan jarak tanam yang lebar dapatmemperbaiki total penangkapan cahaya oleh tanamandan meningkatkan pertumbuhan dan hasil tanaman.. Kondisi ini mengakibatkan fotosintesis berjalan dengan baik, sehingga fotosintat yang dihasilkan dialokasikan untuk pertumbuhan tinggi tanaman.

Uji lanjut perlakuan pengaruh pola tanam dan waktu pembersihan gulma terhadap tinggi tanaman disajikan pada Tabel 2. Pada Tabel 2 tampak bahwa waktu pembersihan gulma pada 5 dan 7 MST menghasilkan tinggi tanaman minggu ke 9 tertinggi yaitu 114,32 cm, sedangkan tinggi tanaman terrendah terdapat pada waktu pembersihan gulma 5 MST yaitu 107,60 cm. Hal ini diduga karena pada waktu pembersihan gulma 5 dan 7 MST tanaman mendapatkanunsur hara, air dan cahaya matahari yang lebihbanyak, dan kompetisi terhadap gulma 
rendah. Fitriana (2008) menyatakan bahwagulma yang tumbuh bersama tanamandapat mengurangi kualitas dan kuantitashasil tanaman karena gulma menjadipesaing dalam pengambilan unsur hara, air,dan cahaya matahari serta menjadi inang hama danpenyakit. Pada penelitian ini diduga waktu pembersihan gulma 5 dan 7 MST memiliki persaingan yang lebih kecil antara gulma dengan tanaman dari pada waktu pembersihan gulma 5 MST sehingga pertumbuhannya lebih baik.

Tabel 2. Pengaruh waktu pembersihan gulma terhadap rerata tinggi tanaman

\begin{tabular}{cc}
\hline Waktu Pembersihan Gulma & Tinggi Tanaman $(\mathrm{cm})$ umur 9 MST \\
\hline 3 MST & $108,47 \mathrm{bc}$ \\
5MST & $107,60 \mathrm{c}$ \\
7MST & $108,26 \mathrm{bc}$ \\
3dan 5MST & $112,32 \mathrm{ab}$ \\
5dan 7MST & $114,32 \mathrm{a}$ \\
\hline
\end{tabular}

Keterangan: Angka-angka pada kolom yang sama yang diikuti oleh huruf yang sama berbeda tidak nyata pada DMRT $5 \%$.

Anakan padi merupakan perkembangan percabangan dari sumbu daun pada setiap buku tajuk utama yang tak memanjang selama pertumbuhan vegetatif (Yoshida, 1981).Nilai rerata pengaruh pola tanam dan waktu pembersihan gulma terhadap jumlah anakan per rumpun disajikan pada Tabel 3.

Tabel 3. Pengaruh pola tanam dan waktu pembersihan gulma terhadap rerata jumlah anakan per rumpun (batang)

\begin{tabular}{|c|c|}
\hline Perlakuan & $\begin{array}{l}\text { Jumlah anakan per rumpun } \\
\text { (batang) }\end{array}$ \\
\hline \multicolumn{2}{|l|}{ Pola Tanam: } \\
\hline Jajar Legowo & 19,39 \\
\hline Tegel & 20,54 \\
\hline \multicolumn{2}{|l|}{ Waktu Pembersihan Gulma: } \\
\hline $3 \mathrm{MST}$ & 19,43 \\
\hline $5 \mathrm{MST}$ & 21,50 \\
\hline 7MST & 20,17 \\
\hline 3dan 5MST & 20,72 \\
\hline 5dan 7MST & 21,38 \\
\hline
\end{tabular}

Pada pola tanam tegel menghasilkan jumlah anakan per rumpun cenderung lebih banyak dari jajar legowo. Hasil tersebut sejalan dengan penelitian Pratiwi et al., (2010) bahwa jarak tanamlebar memberi peluang varietas tanaman 
mengekspresikanpotensi pertumbuhannya.Semakin rapat populasitanaman, maka semakin sedikit jumlah anakan yang terbentuk.

Secara umum hasil penelitian menunjukkan bahwa waktu pembersihan gulma

5MST menghasilkan jumlah anakan per rumpun cenderung lebih tinggi dari waktu pembersihan gulma 3, 7, 3 dan 5 serta 5 dan 7 MST. Sedangkan waktu pembersihan gulma 3 MST cenderung menghasilkan jumlah anakan per rumpun lebih sedikit dari pada waktu pembersihan gulma 5 MST, 7 MST, 3 dan 5 MST, serta 5 dan 7 MST. Hal ini diduga disebabkan bahwa waktu pembersihan gulma 3MST menghasilkan populasi gulma yang lebih tinggi sehingga tanaman akan bersaing dengan gulma dalam memperoleh hara.Dengan demikian, hara yang diperlukan untuk pertumbuhan dan perkembangan tanaman padi lebih sedikit dibandingkan dengan waktu pembersihan gulma lainnya.

Indeks luas daun (ILD) merupakan rasio antaraluas daun (satu permukaan saja) tanaman budidaya terhadap luas tanah (Gardneret al., 1991). Hasil penelitian pengaruh pola tanam dan waktu pembersihan gulma terhadap indeks luas daun padi disajikan pada Tabel 4.

Tabel 4. Pengaruh pola tanam dan waktu pembersihan gulma terhadap ILD

\begin{tabular}{ll}
\hline \multicolumn{1}{c}{ Perlakuan } & Indeks Luas Daun umur 9 MST \\
\hline Pola Tanam: & \\
Jajar Legowo & $9,78 \mathrm{a}$ \\
Tegel & $4,28 \mathrm{~b}$ \\
\hline Waktu Pembersihan Gulma: & \\
3 MST & 6,97 \\
5MST & 6,87 \\
7MST & 6,82 \\
3dan 5MST & 6,98 \\
5dan 7MST & 7,51 \\
\hline
\end{tabular}

Keterangan: Angka-angka pada kolom yang sama yang diikuti oleh huruf yang sama berbeda tidak nyata pada uji DMRT5\%.

Uji lanjut parameter Indek Luas Daun (ILD) minggu 9 padi jajar legowo menghasilkan ILD lebih tinggi dari pola tanam tegel. ILD rata-rata pada pola tanam jajar legowo adalah 9,78, sedangkan rata-rata pada pola tanam tegel adalah 4,28. Nurlaili (2011) menyatakan bahwasemakin lebar jarak tanam maka indeks luas daunnya semakin kecil.Menurut Anggraini et al. (2013) tanaman padi dengan 
pola tanam jajar legowo (jarak tanam 20 x $40 \mathrm{~cm}$ ) menghasilkan ILD lebih rendah daripada pola tanam tegel (jarak tanam 20 x $20 \mathrm{~cm}$ ). ILD pada pola tanam jajar legowo adalah sebesar 4,26sedangkan pola tanam tegel 4,39.Nilai ILD suatu tanaman berhubunganerat dengan berat kering tanaman. Bila ILD terusmeningkat maka berat kering akanmenurun. Penurunan berat kering inidisebabkan laju fotosintesis berkurangkarena daun saling menaungi sehingga proses fotosintesa terganggu (Abdullahet al., 2008).

Hasil merupakan akhir dari proses atau aktivitas yang dapat menghasilkan dengan memanfaatkan beberapa masukan atau input. Hasil tanaman berkaitan dengan cara bagaimana sumber daya dipergunakan untuk menghasilkan (Joesron et al., 2003). Faktor yang mempengaruhi hasil tanaman adalah kesuburan lahan dan tehnik budidaya (Sudalmi dan Sri, 2010). Pengaruh pola tanam dan waktu pembersihan gulma terhadap komponen hasil padi disajikan pada Tabel 5.

Tabel 5. Rerata komponen hasil pada pola tanam dan waktu pembersihan gulma

\begin{tabular}{cccccc}
\hline \multirow{2}{*}{ Perlakuan } & \multicolumn{5}{c}{ Komponen Hasil } \\
\cline { 2 - 6 } & PM $(\mathrm{cm})$ & $\begin{array}{l}\text { JGPM } \\
\text { (bulir) }\end{array}$ & B.1000 (g) & PGH (\%) & BGKG (g) \\
\hline Pola Tanam: & & & & 18,66 & $35,89^{*}$ \\
Jajar Legowo & 23,21 & 159,34 & 24,34 & 18,40 & $43,91^{*}$ \\
Tegel & 23,29 & 160,71 & 24,21 & & \\
\hline Waktu Pembersihan Gulma: & & & 19,08 & 39,47 \\
3 MST & 22,45 & 159,04 & 24,15 & 18,67 & 38,37 \\
5 MST & 23,22 & 154,69 & 24,28 & 19,06 & 37,77 \\
7 MST & 23,28 & 156,58 & 24,48 & 18,55 & 42,34 \\
3 dan 5 MST & 23,90 & 161,42 & 24,43 & 17,30 & 41,54 \\
5 dan 7 MST & 23,38 & 168,38 & 24,02 &
\end{tabular}

Keterangan : $\quad \mathrm{PM}=$ Panjang Malai, JGPM = Jumlah Bulir Gabah Per Malai, B1000 = bobot 1000 Butir Gabah, PGH = Persentase Gabah Hampa, dan BGKG = Bobot Gabah Kering Giling. *berbeda nyata

Hasil penelitian menunjukkan bahwa pola tanam tegel menghasilkan panjang malai cenderung lebih panjang, jumlah gabah per malai cenderung lebih banyak, bobot 1000 butir gabah cenderung lebih berat, persentase gabah hampa cenderung lebih kecil, dan bobot gabah kering giling lebih berat daripada pola tanam jajar legowo. Hal ini diduga disebabkan pada perlakuan ini jarak tanam tegel lebih lebar daripada jarak tanam jajar legowo, sehingga akan lebih banyak mendapatkan unsur hara dan memperoleh sinar matahari lebih banyak. Dengan 
kata lain, persaingan antar tanaman pada pola tanam tegel lebih kecil daripada pola tanam jajar legowo. Kuswara dan Alik (2003) menyatakan bahwa jaraktanam yang lebar akan meningkatkan hasil tanaman, karena akar antara tanamanyang satu dengan akar tanaman yang lain tidak saling bertemu dalammemperebutkan hara mineral dari dalam tanah, begitu pula dengan daun tidak terjadi perebutan dalam memperoleh cahaya matahari.Penelitian Masdar et al. (2005) menunjukkan hasil bahwa semakin lebar jarak tanam, maka jumlah malai semakin banyak dibandingkan jarak tanam yanglebih rapat. Sebaliknya, pada jarak tanam rapat jumlah malai per rumpun menurun (Mobasser et al., 2009). Jarak tanam mempengaruhi panjang malai, jumlah bulirper malai, dan hasil per ha tanaman padi (Salahuddin et al., 2009). Sohel et al, (2009) menambahkan bahwa jarak tanam yangoptimum akan memberikan pertumbuhan bagian atastanaman dan pertumbuhan bagian akar yang baiksehingga dapat memanfaatkan lebih banyak cahayamatahari serta memanfaatkan lebih banyak unsur hara. Sebaliknya, jarak tanam yang terlalu rapat akan mengakibatkan terjadinya kompetisi antar tanaman yangsangat hebat dalam hal cahaya matahari, air, dan unsurhara. Akibatnya, pertumbuhan tanaman terhambat dan hasil tanaman rendah.

Hasil penelitian menunjukkan bahwa pembersihan gulma yang dilakukan sebanyak dua kali menghasilkan jumlah anakan produktif, panjang malai, jumlah gabah per malai, bobot 1000 butir gabah, persentase gabah hampa, dan bobot gabah kering giling lebih baik daripada pembersihan gulma yang dilakukan hanya sekali. Hal ini diduga penyiangan yang hanya dilakukan sekali menyebabkan tingkat pertumbuhan gulma menjadi lebih banyak dan lebih cepat sehingga menimbulkan persaingan antara gulma dengan tanaman. Hal ini sejalan dengan pendapat Jatmiko et al. (2002) bahwa gulma berinteraksi dengan tanaman melalui persaingan untuk mendapatkan satu atau lebih faktor tumbuh yang terbatas, seperti cahaya, hara, dan air. Menurut Fadli et al. (2013) bahwa penyiangan padapertanaman padi harus dilakukan dengan cepat untuk mengindari tanaman menjadi kerdilkarena terjadinya perebutan unsur hara.

Hasil sidik ragam menunjukkan bahwa bobot gabah kering giling pada pola tanam tegel berbeda nyata dengan bobot gabah kering giling pada pola tanam jajar legowo.Pola tanam tegel menghasilkan bobot gabah kering giling lebih tinggi 
daripada pola tanam jajar legowo. Pola tanam tegel menghasilkan 43,91 gram, sedangkan pada pola tanam jajar legowo menghasilkan 35,89 gram. Hal ini diduga karena pada pola tanam tegel cenderung menghasilkan jumlah anakan dan jumlah malai lebih banyak daripada pola tanam jajar legowo. Menurut Vergara (1990) faktor penting untuk memperolehhasil gabah yang banyak adalah jumlah anakan dan jumlah malai yang terbentuk. Semakin banyak anakan yang menghasilkan malai maka akan semakin banyak pula gabah yang dihasilkan. Meskipun bobot gabah per rumpun tertinggi dicapai pada pola tanam tegel, namun hasil per petak tertinggi diperoleh dari pola tanam legowo dengan hasil $5,74 \mathrm{~kg}$ GKG. Sedangkan pola tanam tegel hanya mencapai 4,22 kg GKG per petak. Hal ini sesuai dengan hasil-hasil penelitian yang dilakukan BPTP tahun 2010 dan 2013 yang menunjukkan bahwa pola tanam legowo menghasilkan GKG lebih tinggi dibandingkan pola tanam tegel.

Hasil sidik ragam menunjukkan adanya interaksi yang nyata antara pola tanam padi dan waktu pembersihan gulma terhadap jumlah anakan produktif. Hasil uji dwi arah pengaruh pola tanam dan waktu pembersihan gulma terhadap jumlah anakan produktif disajikan pada Tabel 6.

Tabel 6. Hasil uji dwi arah pengaruh pola tanam dan waktu pembersihan gulma terhadap jumlah anakan produktif padi sawah (batang)

\begin{tabular}{|c|c|c|c|c|c|}
\hline \multirow{2}{*}{ Pola Tanam } & \multicolumn{5}{|c|}{ Waktu Pembersihan Gulma (MST) } \\
\hline & 3 & 5 & 7 & 3 dan 5 & 5 dan 7 \\
\hline Jajar Legowo & $\begin{array}{c}11,56 \\
c\end{array}$ & 14,33 abc & $13,76 \mathrm{bc}$ & $13,43 \mathrm{bc}$ & $13,23 \mathrm{bc}$ \\
\hline & B & & & & \\
\hline Tegel & $\begin{array}{c}17,23 \mathrm{a} \\
\mathrm{A}\end{array}$ & $13,53 \mathrm{bc}$ & $14,83 \mathrm{ab}$ & $15,93 \mathrm{ab}$ & $16,26 \mathrm{ab}$ \\
\hline
\end{tabular}

Keteerangan : Angka-angka yang diikuti oleh huruf kecil yang sama pada baris yang samadan huruf besar pada kolom yang sama berbeda tidak nyata pada uji DMRT 5\%.

Interaksi antara pola tanam jajar legowo menunjukkan waktu pembersihan gulma terbaik adalah pada umur 5 MST dengan nilai rata-rata jumlah anakan produktif 14,33 batang berbeda tidak nyata dengan waktu pembersihan gulma pada umur 3, 7, 3 dan 5, serta 5 dan 7 MST. Sedangkan pada pola tanam tegel, 
waktu bembersihan gulma terbaik pada umur 3 MST dengan nilai rata-rata jumlah anakan produktif 17,23 batang yang berbeda tidak nyata dengan waktu pembersihan gulma pada umur 7 MST, 3 dan 5 MST, serta 5 dan 7 MST, tetapi berbeda nyata dengan waktu pembersihan gulma pada umur 5 MST.

Pola tanam tegel menghasilkan jumlah anakan produktif yang berbeda nyata pada saat pembersihan gulma dilakukan 3 MST, lewat dari waktu pembersihan gulma tersebut menghasilkan jumlah anakan produktif yang tidak berbeda nyata. Meskipun demikian, tampak bahwa jumlah anakan produktif pada pola tanam tegel cenderung lebih tinggi daripada pola tanam jajar legowo. Pola tanam tegel menghasilkan nilai rata-rata jumlah anakan produktif lebih tinggi dari pada pola tanam jajar legowo.Hal ini karena jarak tanam tegel lebih lebar dari pada jarak tanam jajar legowo. Suryanto(2010) menyatakan bahwa penggunaan jarak tanam lebar bertujuan untukmeningkatkan jumlah anakan produktif. Semakin banyak jumlah anakan produktif maka semakin banyak hasil tanaman padi.

Selain itu diduga pada umur 3 MST merupakan periode kritis pengendalian gulma. Pengendalian gulma harus dilakukan tepat pada waktunya. Banyak penelitian yang menunjukkan bahwa mengendalikangulma sepanjang periode pertumbuhantanaman memberikan hasil yang sama dengan mengendalikan gulma hanya padaperiode kritis tanaman. Moenandir (1988) menyatakan bahwa mengendalikan gulma pada umur 21-28 HST daritanaman jagung memberikan hasil yang sama dengan mengendalikan gulma sepanjang siklus hidup tanaman jagung. Menurut Sukman dan Yakup (2002) bahwa pada periode kritis ini sesungguhnya gulma harus dikendalikan karena merupakan waktu yang tepat untuk mengendalikan gulma yang mempunyai makna yaitu mengendalikan gulma secara efektif dan efesien sehingga menghemat waktu, tenaga, dan biaya. Mercado (1979) menyatakan bahwa periode kritis tanaman akibat persaingan gulma terjadi antara 1/3-1/2 dari umur tanaman atau periode kritis biasanya bermula pada umur 3-6 minggu setelah tanam dan akan terus berlangsung selama tiga minggu. 


\section{KESIMPULAN DAN SARAN}

\section{Kesimpulan}

Berdasarkan kepada hasil penelitian ini dapat disimpulkan hal sebagai berikut:

1. Waktu pembersihan gulma 5 dan 7 MST menghasilkan tinggi tanaman tertinggi yaitu $144,32 \mathrm{~cm}$, dan berat gabah per rumpun terberat yaitu 43,91gram.

2. Pola tanam tegel menghasilkan tinggi tanaman tertinggi yaitu $112,28 \mathrm{~cm}$, jumlah anakan produktif terbanyak yaitu 15,55 batang, bobot gabah kering terberat yaitu 43,91 gram. Sedangkan pola tanam jajar legowo menghasilkan indeks luas daun tertinggi yaitu 9,78 serta hasil per petak tertinggi sebesar $5,74 \mathrm{~kg} \mathrm{GKG.}$

3. Perlakuan pola tanam tegel dan waktu pembersihan gulma 3 MST menghasilkan jumlah anakan produktif terbanyak yaitu 17,23 batang.

\section{Saran}

Dilakukan penelitian lanjutan dengan menggunakan perlakuan jarak tanam jajar legowo yang lebih luas untuk mendapatkan jarak tanam yang optimum untuk pertumbuhan dan hasil tanaman padi.

\section{DAFTAR PUSTAKA}

Abdullah B., S.Tjokrowidodo, dan Sularjo. 2008. Perkembangan dan Prospek Perakitan Padi Tipe Baru di Indonesia. Jurnal Litbang Pertanian,27 (1)

Anggraini, Suryanto, dan Aini. 2013. Sistem Tanam dan Umur Bibit pada Tanaman Padi Sawah (Oryza sativa L.) Varietas INPARI 13. Jurnal Produksi Tanaman 1 (2)

Bayong, T.H.K., 2004.Klimatologi. Penerbit ITB, Bandung

BPTP. 2013. Petunjuk Teknis Pengelolaan Tanaman Terpadu. Balai Pengkajian Teknologi Pertanian (BPTP) Jambi. Balai Besar Pengkajian dan Pengembangan Pertanian. Badan Penelitian dan Pengembangan Pertanian. Kementerian Pertanian. 
Fadli, H.N., G. Jonathan, dan S. Balonggu. 2013. Tanggap Pertumbuhan dan Produksi Padi Gogo Varietas Situ Bagendit Terhadap Pengolahan Tanah dan Frekuensi Penyiangan yang Berbeda. J. Agroekoteknologi.Vol. 1, No2

Fitriana, M. 2008. Pengaruh Periode Penyiangan Gulma Terhadap Pertumbuhan dan Hasil Tanaman Kacang Hijau (Vigna radiata L.) Varietas Kenari. Jurnal Agria 5 (1): 1-4.

Gardner F.P, R.B. Pearce, and R.L. Mitchell. 1991. Physiology of Crop Plants. Diterjemahkan oleh H.Susilo. Jakarta. Universitas Indonesia Press.

Hermawati, T. 2012. Pertumbuhan dan Hasil Enam Varietas Padi Sawah Dataran Rendah pada Perbedaan Jarak Tanam. Jurnal Bioplantae. 1 (2): 108-116.

Ihwani, G.R. Pratiwi, E. Paturrohman, dan Makarim. 2013. Peningkatan Produktivitas Padi Melalui PenerapanJarak Tanam Jajar Legowo. Iptek Tanaman Pangan Vol. 8 No. 2

Jatmiko, S.Y., S. Harsanti, Sarwoto, dan A.N. Ardiwinata. 2002. Apakah Herbisida yang Digunakan Cukup Aman? hlm. 337-348. Dalam J. Soejitno, I.J. Sasa, dan Hermanto (Ed.). Prosiding Seminar Nasional Membangun Sistem Produksi Tanaman Pangan Berwawasan Lingkungan. Pusat Penelitian dan Pengembangan Tanaman Pangan, Bogor.

Joesron, T. Suhartati, dan M. Fathorrozi, 2003, ”Teori Ekonomi Mikro,Dilengkapi Beberapa Bentuk Fungsi Produksi”, Penerbit Salemba Empat, Jakarta.

Kuswara, E dan S. Alik. 2003. Dasar Gagasan dan Praktek Tanam PadiMetode SRI. KSP Mengembangkan Pemikiran Untuk Membangun Pengetahuan Petani Jawa Barat

Lin, X.Q., D.F. Zhu, H.Z. Chen, and Y.P. Zhang. 2009. Effects of Plant Density and Nitrogen Application Rate on Grain Yield and Nitrogen Uptake of Super Hybrid Rice. Rice Science 16(2):138-142

Masdar,K. Musliar, R.Bujang, N. Hakim, dan Helmi. 2005. Interaksi JarakTanam dan Jumlah Bibit per Titik Tanam pada Sistem Intensifikasi Padi Terhadap Pertumbuhan Vegetatif Tanaman. Akta Agrosia Ed Khusus. (1) :92-98

Mercado, B.L. 1979. Introduction to Weed Science. Searca Pub., Los Banos, Laguna, the Philippines. 279 pp.

Mobasser,H.R., R. Yadi, M. Azizi, A.M. Ghanbari, and M. Samdalari. 2009 Effect of Density on Morphological Characteristics Related-Lodging on Yield and Yield Components in Varieties Rice (Oryza sativa L.) in Iran. $J$. Agric. and Environ. Sci. 5(6):745-754

Moenandir J. 1988 Ilmu Gulma.Malang:Universitas Brawijaya Press. 
Nurlaili. 2011. Optimalisasi Cahaya Matahari pada Pertanaman Padi (Oryza sativa L.) System of Rice Intensification (SRI) Melalui Pendekatan Pengaturan Jarak Tanam. AgronobiS, Vol. 3, No. 5

Pahruddin, A. Maripul, dan P. Rido. 2004. Cara Tanam Padi Sistem Legowo Mendukung Usaha Tani di Desa Bojong, Cikembar Sukabumi. Buletin Teknik Pertanian 9 (1).

Partohardjono, S dan A. Makmur. 1989. Peningkatan Produksi Padi Gogo. Dalam Padi. Buku 2. Penyunting Ismunadji dkk. Badan Penelitian dan Pengembangan Pertanian, Pusat Penelitian dan Pengembangan Tanaman Pangan, Bogor, Hal: 523-549.

Pratiwi, G.R., E. Suhartatik, dan A.K. Makarim. 2010.Produktivitas dan Komponen Hasil Tanaman Padisebagai Fungsi dari Populasi Tanaman. In: S.Abdulrachman, H.M. Toha, dan A. Gani (Eds.). InovasiTeknologi Padi untuk Mempertahankan Swasembada dan Mendorong Ekspor Beras.Prosiding Seminar nasional Hasil Penelitian Padi2009, Buku 2. Balai Besar Penelitian Tanaman Padi.p.443-450

Purwono, L. dan Purnamawati. 2007. Budidaya Tanaman Pangan. Penerbit Agromedia. Jakarta.

Rudiyono. 2016. Pengaruh Frekuensi Penyiangan Gulma terhadap Pertumbuhan dan Hasil Beberapa Varietas Padi Sawah (Oryza sativa L.). SKRIPSI. Departemen Agronomi dan Hortikultura Fakultas Pertanian Institut Pertanian Bogor, Bogor.

Salahuddin, K.M., S.H. Chowhdury, S. Munira, M.M.Islam, and S. Parvin. 2009. Response of Nitrogen and Plant Spacing of Transplanted Aman Rice.Bangladesh J. Agric. Res. 34(2): 279-285

Sohel, M. A. T., M. A. B. Siddique, M. Asaduzzaman, M. N. Alam, and M.M. Karim. 2009. Varietal Performance of Transplant Aman Rice Under Different Hill Densities. Bangladesh J. Agric. Res. 34(1): 33-39

Sudalmi, dan E. Sri. 2010. Pembangunan Pertanian Berkelanjutan. Innofarm: Jurnal Inovasi Pertanian Vol.9, No. 2, September 2010 (15 -28). 13 hal.

Sukman, Y. dan Yakup. 2002. Gulma dan TeknikPengendaliannya: Palembang, Fakultas Pertanian Universtias Sriwijaya Palembang

Suriapermana, S., N. Indah, dan Y. Surdianto. 2000. Teknologi Budidaya Padi dengan Cara Tanam Legowo pada Lahan Sawah Irigasi. Simposium Penelitian Tanaman Pangan IV : Tonggak Kemajuan Teknologi Produksi Tanaman Pangan. Pusat Penelitian dan Pengembangan Tanaman Pangan. Bogor. p 125-135.

Suryanto, A. 2010.Budidaya Padi Sawah. dalam Pertanian Berkelanjutan Berbasis Padi Sawah Melalui Jembatan SRI. Sampoerna - FP UB. p. 73 - 86. 
Agritrop, Vol. 16 (1): 1 - 16

Vergara, B.S. 1990. Bercocok Tanam Padi. Proyek Prasarana Fisik Bappenas. Jakarta.

Yoshida, S. 1981. Fundamentals of Rice Crop Science. IRRI. Los Banos. Laguna, Philippines. 